\title{
Deuterium-Labeled Precursor Feeding Reveals a New pABA-Containing Meroterpenoid from the Mango Pathogen Xanthomonas citri pv. mangiferaeindicae
}

Hesham Saleh $^{1}$, Daniel Petras ${ }^{1}$, Andi Mainz ${ }^{1}$, Dennis Kerwat ${ }^{1}$, Ayse Nalbantsoy ${ }^{2}$, Yalcin Erzurumlu ${ }^{3}$ and Roderich D. Süssmuth ${ }^{1}$

${ }^{1}$ Institut für Chemie, Technische Universität Berlin, Strasse des 17. Juni 124, 10623 Berlin, Germany

${ }^{2}$ Department of Bioengineering, Faculty of Engineering, Ege University, 35100 Bornova Izmir, Turkey

${ }^{3}$ Department of Biochemistry, Faculty of Pharmacy, Ege University, 35100 Bornova Izmir, Turkey 


\section{Contents:}

Synthesis of d4-pABA. 3

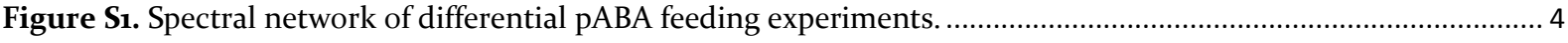

Figure S2. NMR spectra showing the connection between the pABA and terpenoid units....................................... 5

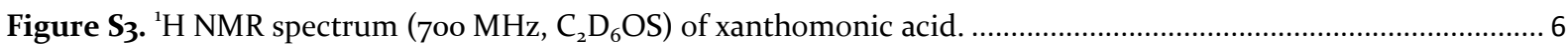

Figure $\mathrm{S}_{4} \cdot{ }^{1} \mathrm{H}-{ }^{1} \mathrm{H}$ COSY spectrum (70o $\left.\mathrm{MHz}, \mathrm{C}_{2} \mathrm{D}_{6} \mathrm{OS}\right)$ of xanthomonic acid....................................................... 7

Figure $\mathrm{S}_{5} \cdot{ }^{1} \mathrm{H}^{-13} \mathrm{C}$ HSQC spectrum (70o $\mathrm{MHz}, \mathrm{C}_{2} \mathrm{D}_{6} \mathrm{OS}$ ) of xanthomonic acid. ....................................................... 8

Figure S6. ${ }^{1} \mathrm{H}^{13} \mathrm{C} \mathrm{HMBC}$ spectrum (70o $\left.\mathrm{MHz}, \mathrm{C}_{2} \mathrm{D}_{6} \mathrm{OS}\right)$ of xanthomonic acid. .................................................... 9

Figure $\mathrm{S}_{7} .{ }^{1} \mathrm{H}-{ }^{1} \mathrm{H}$ ROESY spectrum (70o $\mathrm{MHz}, \mathrm{C}_{2} \mathrm{D}_{6} \mathrm{OS}$, mixing time of $200 \mathrm{~ms}$ ) of xanthomonic acid. .................... 10

Figure S8. Microscopic examination of cancerous and non-cancerous (HEK293) cells compared to the control group $48 \mathrm{~h}$ after treatment with test compounds. 
Synthesis of $d_{4}-p A B A$.

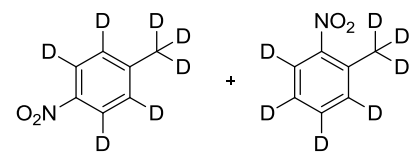

D8-toluene (3.00 $\mathrm{mL}, 2.83 \mathrm{~g}$, and $28.2 \mathrm{mmol}$ ) was stirred in a flask and cooled down to o ${ }^{\circ} \mathrm{C}$. A precooled mixture of conc. $\mathrm{H}_{2} \mathrm{SO}_{4}(3.50 \mathrm{~mL})$ and $\mathrm{HNO}_{3}(65 \% ; 3.00 \mathrm{~mL})$ was slowly added and it was stirred at $\mathrm{o}{ }^{\circ} \mathrm{C}$ for $2 \mathrm{~h}$. After stirring for an additional $2 \mathrm{~h}$ at room temperature the reaction mixture was poured onto ice. The aqueous layer was extracted $3 \mathrm{x}$ with MTBE and the combined organic layers were washed $3 \mathrm{x}$ with $5 \% \mathrm{NaHCO}_{3}$ solution, $\mathrm{H}_{2} \mathrm{O}$ and brine. After drying over $\mathrm{Na}_{2} \mathrm{SO}_{4}$ the solvent was removed. The crude product, which contained the two regioisomeres was used without further purification HRMS (ESI): $[\mathrm{M}+\mathrm{H}]^{+}$calculated $145.0989[\mathrm{M}+\mathrm{H}]^{+}$experimental 145.0992.<smiles>[2H]c1c([2H])c([2H])c([N+](=O)[O-])c(C(=O)O)c1[2H]</smiles>

To a stirred solution of $\mathrm{K}_{2} \mathrm{CrO}_{7}(9.55 \mathrm{~g}, 32.4 \mathrm{mmol}$, $3.00 \mathrm{eq})$ in $30 \% \mathrm{H}_{2} \mathrm{SO}_{4}(60 \mathrm{~mL})$ was added the mixture of the two regioisomeres and it was stirred at $100{ }^{\circ} \mathrm{C}$ for $18 \mathrm{~h}$. After cooling down to room temperature the reaction mixture was poured onto ice. The precipitate was collected and washed with cold water. After drying in vacuo the nitrobenzoates were isolated as pale yellow solids (22\%) - ${ }^{1} \mathrm{H}-\mathrm{NMR}\left(\mathrm{DMSO}_{6}, 500 \mathrm{MHz}\right): \delta[\mathrm{ppm}] 13.62(\mathrm{bs}, 1 \mathrm{H})$; HRMS (ESI):

$[\mathrm{M}+\mathrm{H}]^{+}$calculated 170.0386 $[\mathrm{M}+\mathrm{H}]^{+}$observed 170.394.<smiles>[2H]c1c([2H])c([N+](=O)[O-])c([2H])c([2H])c1C(=O)OCCCCCCCCCC</smiles>

The nitrobenzoates (1.096 g, $6.41 \mathrm{mmol}$, 1.0o eq) were dissolved in DMF (50 mL) and stirred at room temperature. $\mathrm{K}_{2} \mathrm{CO}_{3}$ (2.653 g, $19.23 \mathrm{mmol}$, 3.00 eq) was added, followed by benzylbromide (o.84 mL, $1.205 \mathrm{~g}, 7.05 \mathrm{mmol}, 1.10 \mathrm{eq}$ ). The reaction mixture was stirred overnight and diluted with $\mathrm{EE}$ and the organic layer was washed with $1 \mathrm{~N} \mathrm{HCl}$ and brine. After drying over $\mathrm{Na}_{2} \mathrm{SO}_{4}$ the solvent was evaporated. The crude product which contained the two regioisomers, was chromatographically purified to give the desired regioisomer, benzyl-4-nitrobenzoate, as a yellow liquid (85\%) - ${ }^{1} \mathrm{H}-\mathrm{NMR}\left(\mathrm{DMSO}_{6}, 400 \mathrm{MHz}\right): \delta[\mathrm{ppm}] 4.56(\mathrm{~s}, 2 \mathrm{H}), 6.56\left(\mathrm{~m},{ }_{3} \mathrm{H}\right), 6.65(\mathrm{~m}, 2 \mathrm{H})$; HRMS (ESI): $[\mathrm{M}+\mathrm{H}]^{+}$calculated 262.1012 $[\mathrm{M}+\mathrm{H}]^{+}$observed 262.1392.<smiles>[2H]c1c([2H])c([2H])c(C(=O)O)c([2H])c1[2H]</smiles>

Benzyl-4-nitrobenzoate (1.620 g, $6.21 \mathrm{mmol}$ ) was dissolved in EE/MeOH (9:1) and Pd/C (162 mg) was added. The reaction mixture was stirred under an $\mathrm{H}_{2}$-atmosphere at room temperature. After stirring for $12 \mathrm{~h}$ the mixture was filtered through a pad of celite. After evaporating the solvent the product was obtained as a beige solid (quant.) - ${ }^{1} \mathrm{H}-$ NMR (DMSO-d 6 , $500 \mathrm{MHz}): \delta[\mathrm{ppm}] 5.85(\mathrm{~s}, 2 \mathrm{H}), 11.87(\mathrm{bs}, 1 \mathrm{H}) ;$ HRMS (ESI): $[\mathrm{M}+\mathrm{H}]^{+}$calculated 142.0801 $[\mathrm{M}+\mathrm{H}]^{+}$ observed 142.0798. 

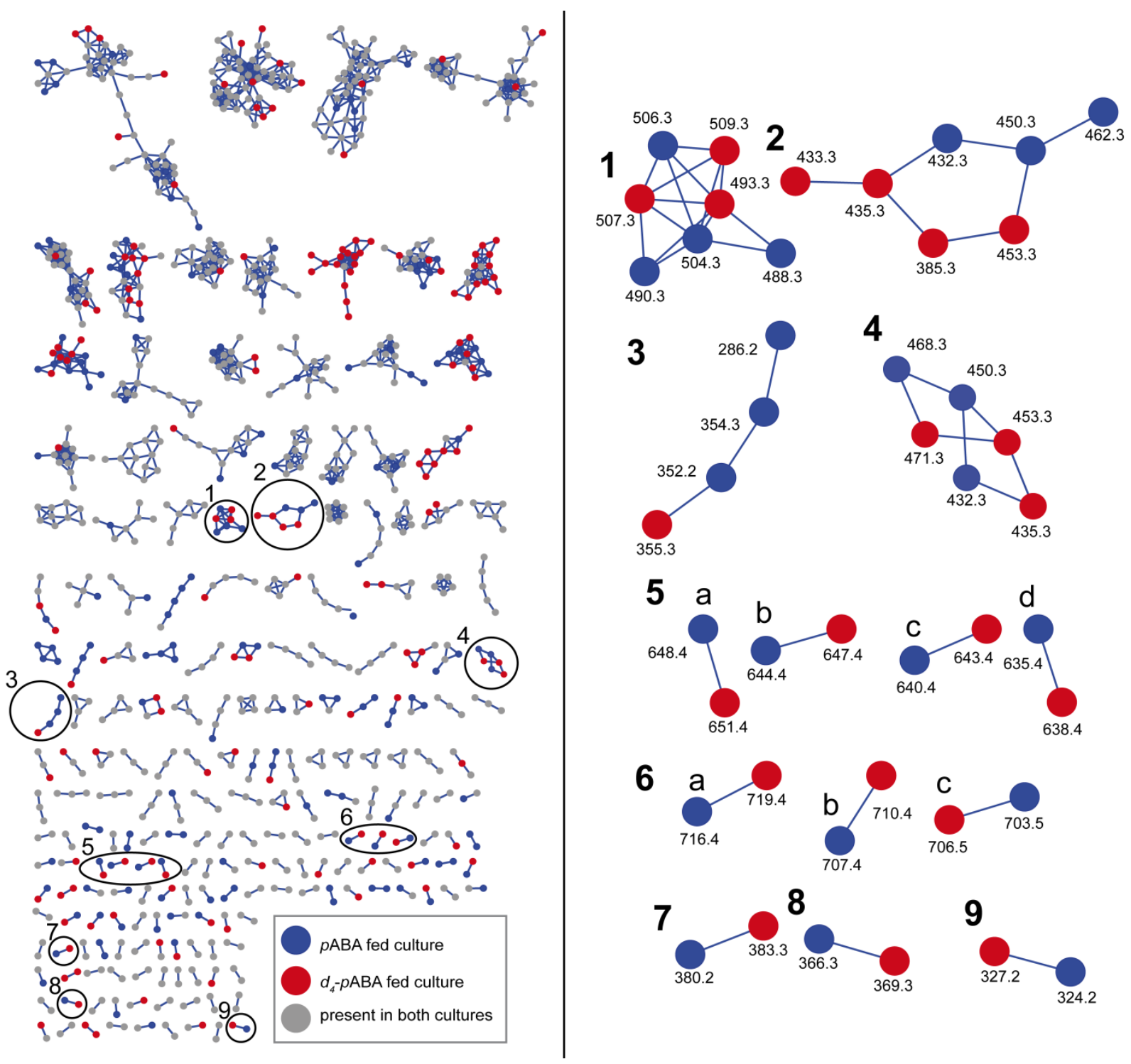

Figure S1. Spectral network of differential pABA feeding experiments. Every node represents clustered MS/MS spectra connected to a set of similar spectra. Blue nodes represent MS/MS spectra obtained exclusively from XAD extracts from cultures fed with $p A B A$, whereas red nodes refer to $d_{4}-p A B A$ cultures. Grey nodes represent spectra found in both feeding experiments. Clusters of putative pABA containing molecules are numbered and enlarged on the right together with the corresponding masses. Cluster number 4 represents xanthomonic acid and is shown in detail with the corresponding mass spectra in Figure 1 B of the main manuscript. 

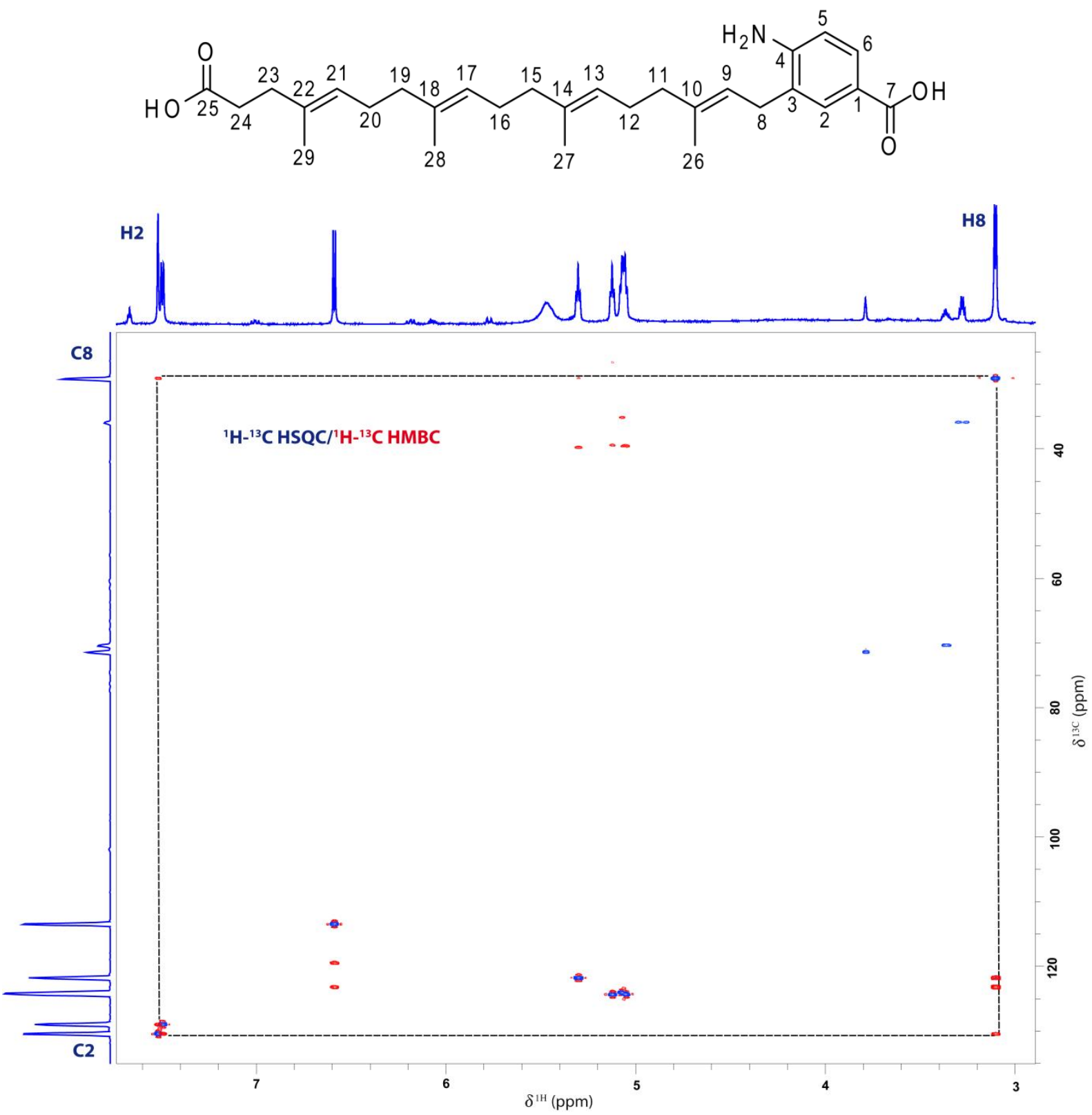

Figure S2. NMR spectra showing the connection between the pABA and terpenoid units. Overlay of selected region in ${ }^{1} \mathrm{H}^{-13} \mathrm{C}$ HSQC (blue) and ${ }^{1} \mathrm{H}^{-13} \mathrm{C}$ HMBC spectra (red). The dashed lines show the correlations for the pABA spin system at $\mathrm{H}_{2} / \mathrm{C}_{2}$ to the terpenoid system at $\mathrm{H} 8 / \mathrm{C} 8$. The top axis shows the recorded ${ }_{1} \mathrm{D} \mathrm{H}-\mathrm{NMR}$ spectrum; and the left side axis shows the projection of the ${ }^{13} \mathrm{C}$ dimension from the $2 \mathrm{D}$ experiment. 


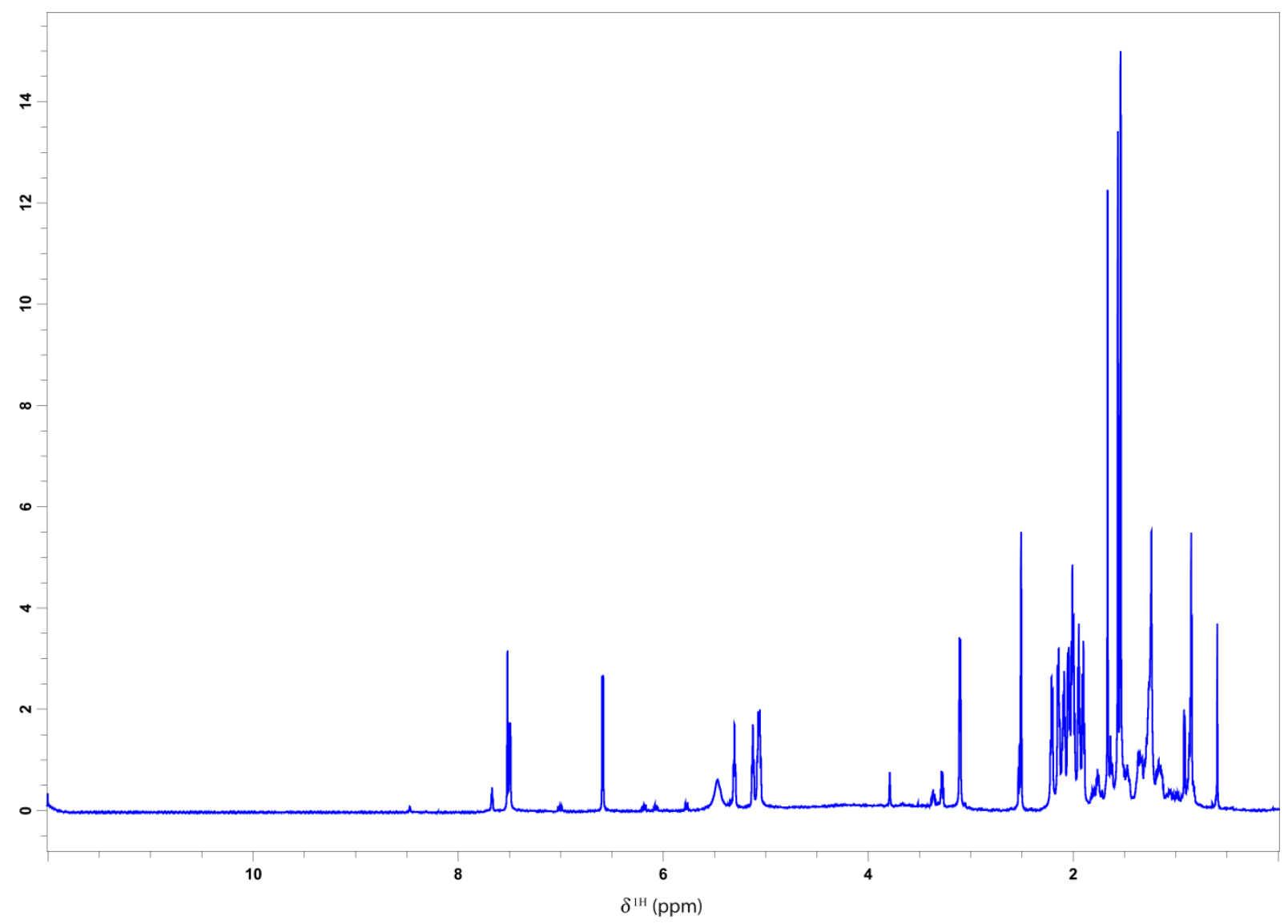

Figure $\mathbf{S}_{3} .{ }^{1} \mathrm{H}$ NMR spectrum (70o MHz, $\left.\mathrm{C}_{2} \mathrm{D}_{6} \mathrm{OS}\right)$ of xanthomonic acid. 


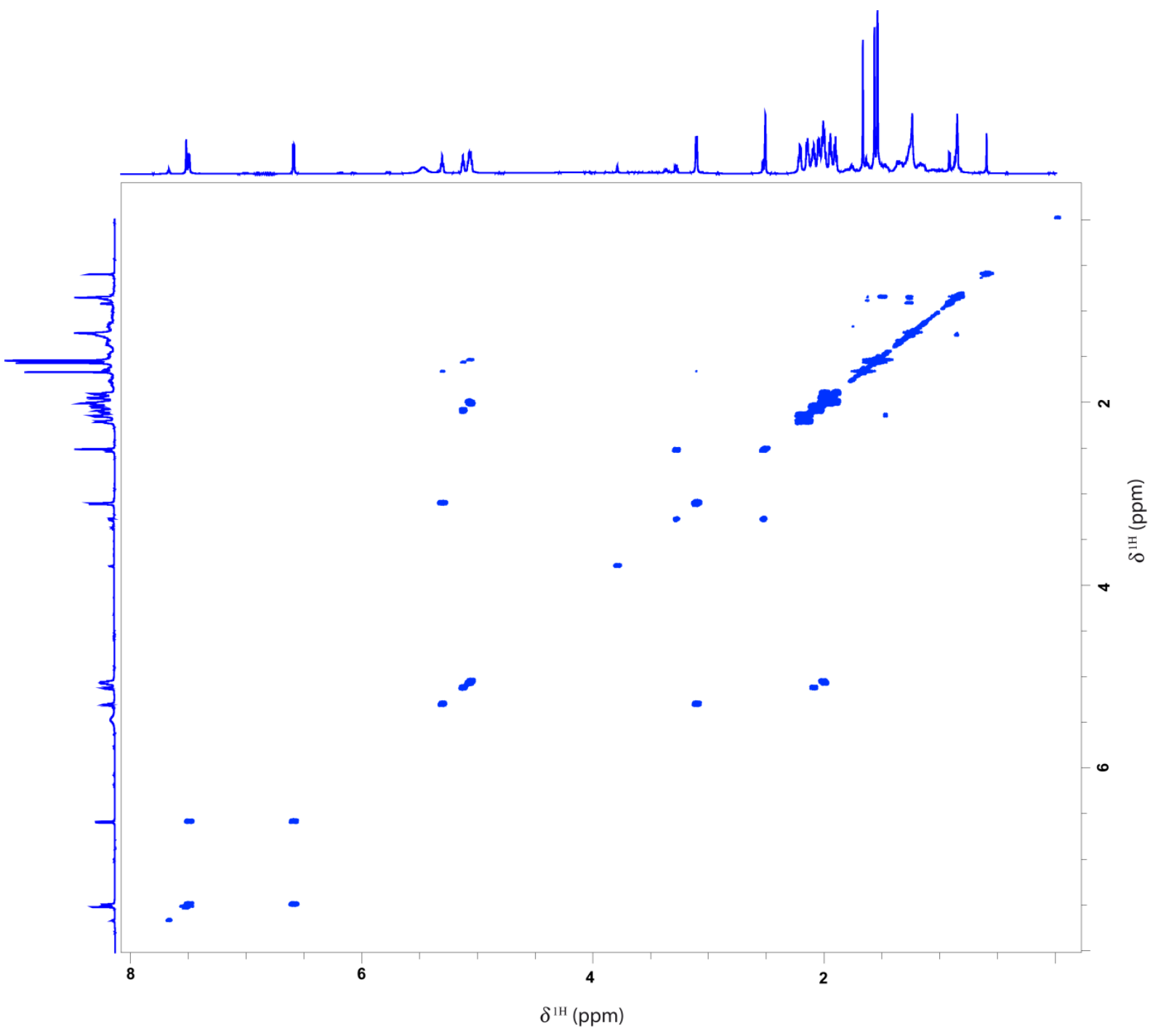

Figure S4. ${ }^{1} \mathrm{H}-{ }^{1} \mathrm{H}$ COSY spectrum (7oo $\mathrm{MHz}, \mathrm{C}_{2} \mathrm{D}_{6} \mathrm{OS}$ ) of xanthomonic acid. The top and left axes show the recorded ${ }_{1} \mathrm{D}^{1} \mathrm{H}$ NMR spectrum. 


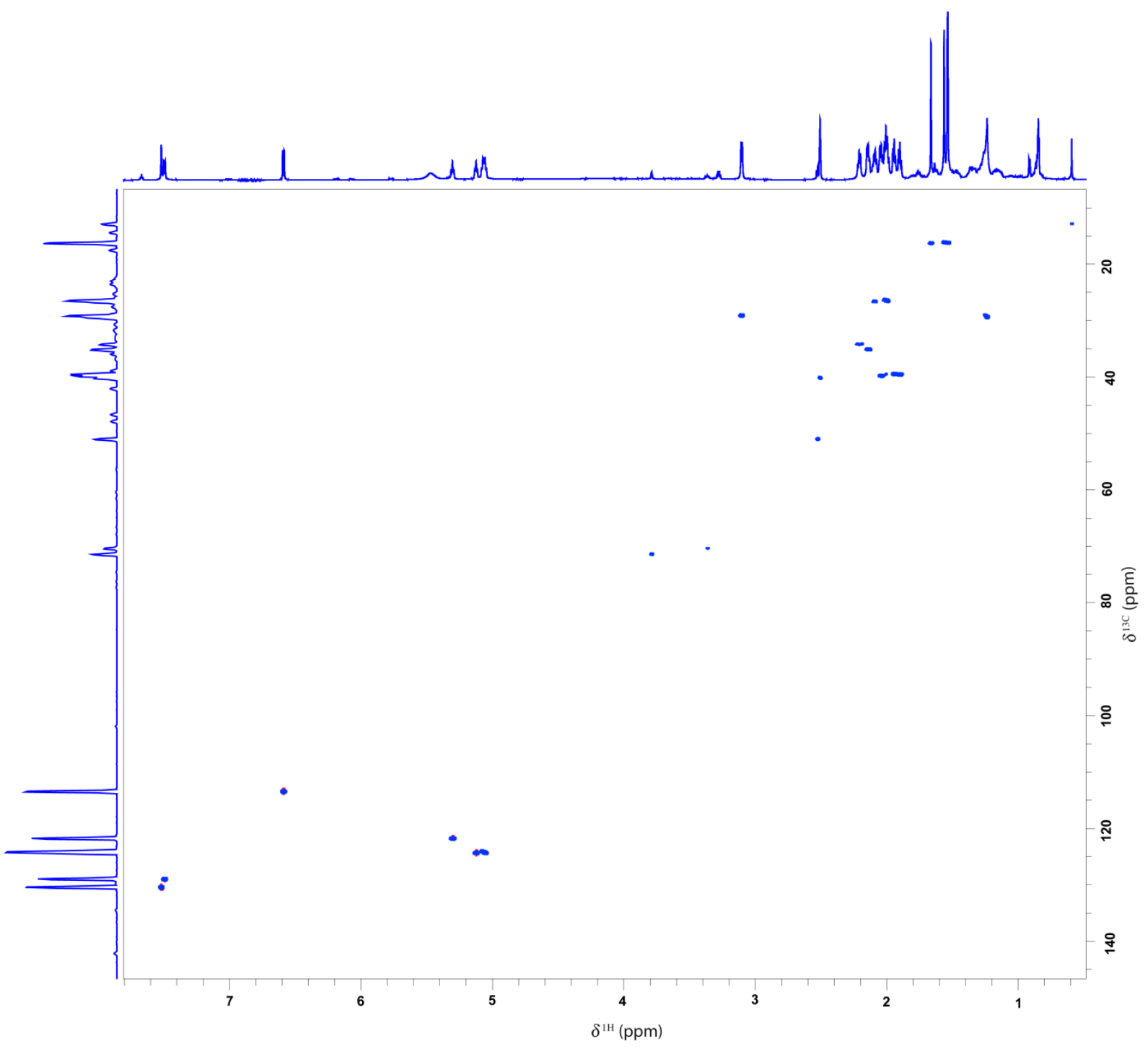

Figure $\mathrm{S}_{5} \cdot{ }^{1} \mathrm{H}-{ }^{13} \mathrm{C}$ HSQC spectrum $\left(700 \mathrm{MHz}, \mathrm{C}_{2} \mathrm{D}_{6} \mathrm{OS}\right)$ of xanthomonic acid. The top axis shows the recorded $1 \mathrm{D}^{1} \mathrm{H}$ NMR spectrum; and the left axis shows the projection of the ${ }^{13} \mathrm{C}$ dimension from the $2 \mathrm{D}$ experiment. 


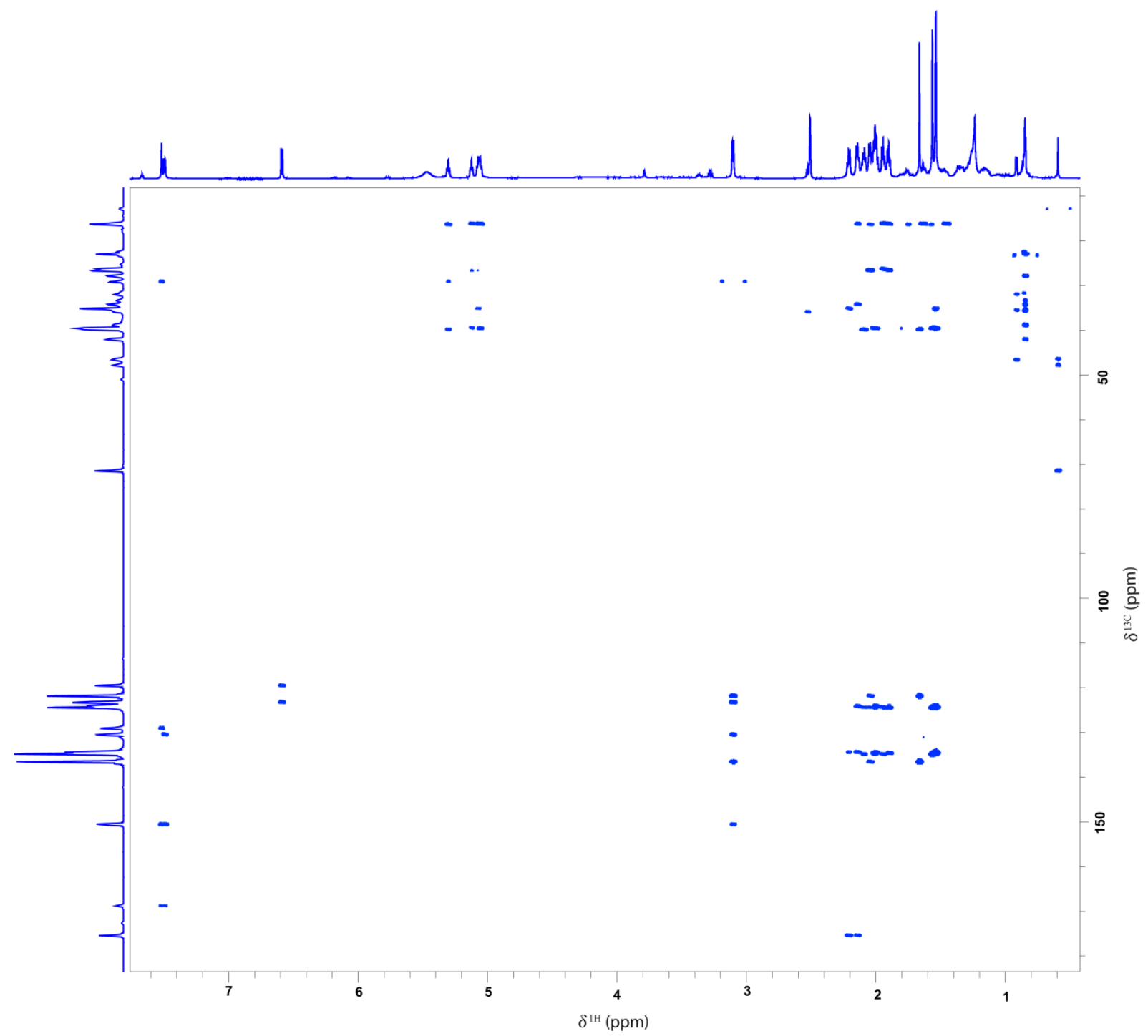

Figure S6. ${ }^{1} \mathrm{H}-{ }^{13} \mathrm{C}$ HMBC spectrum (70o MHz, $\mathrm{C}_{2} \mathrm{D}_{6} \mathrm{OS}$ ) of xanthomonic acid. The top axis shows the recorded ${ }_{1} \mathrm{D}^{1} \mathrm{H}$ NMR spectrum; and the left axis shows the projection of the ${ }^{13} \mathrm{C}$ dimension from the $2 \mathrm{D}$ experiment. 


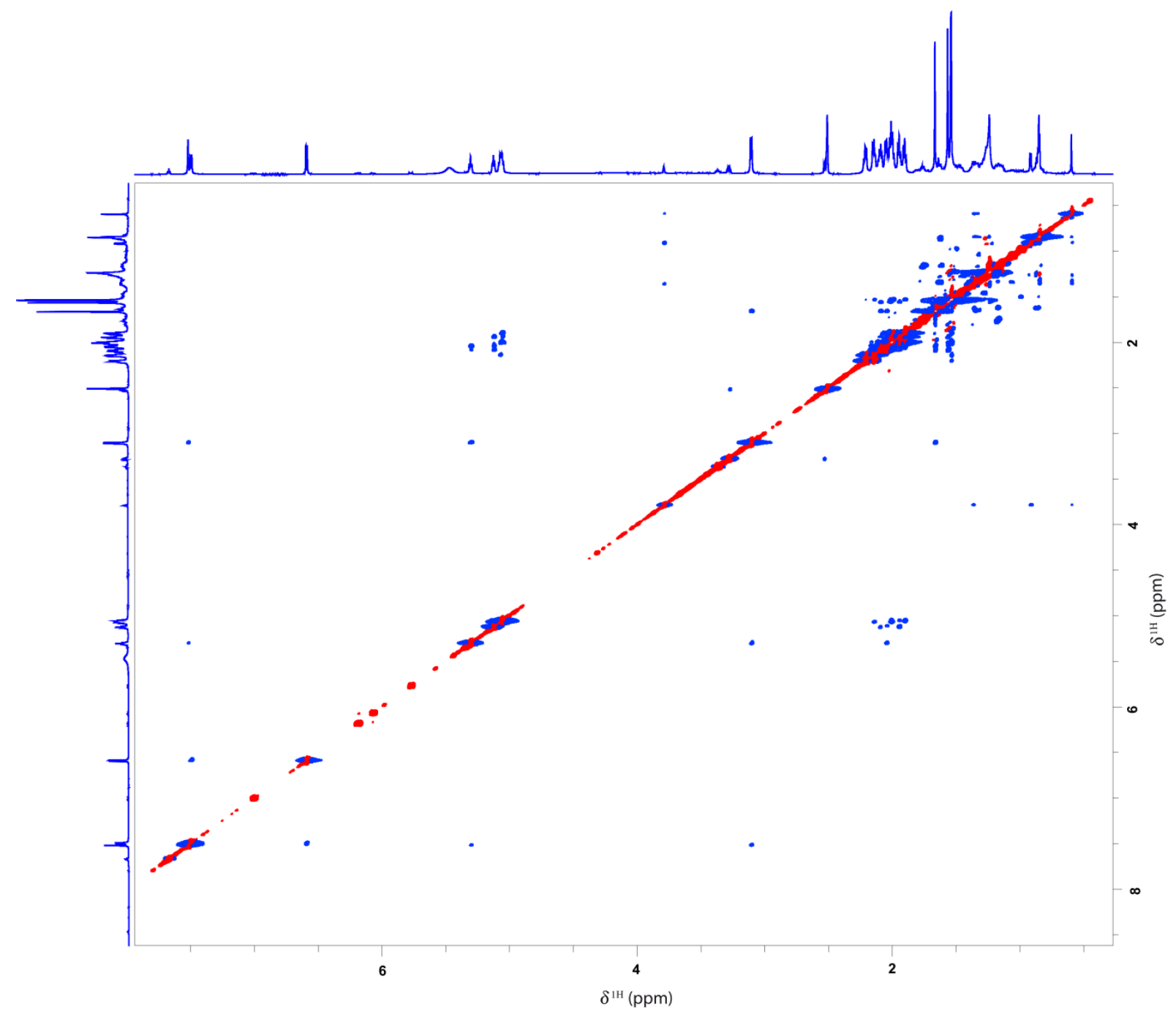

Figure $\mathrm{S}_{7} \cdot{ }^{1} \mathrm{H}-{ }^{1} \mathrm{H}$ ROESY spectrum (70o $\mathrm{MHz}, \mathrm{C}_{2} \mathrm{D}_{6} \mathrm{OS}$, mixing time of $200 \mathrm{~ms}$ ) of xanthomonic acid. The top and left axes show the recorded ${ }_{1} \mathrm{D}^{1} \mathrm{H}$ NMR spectrum. 

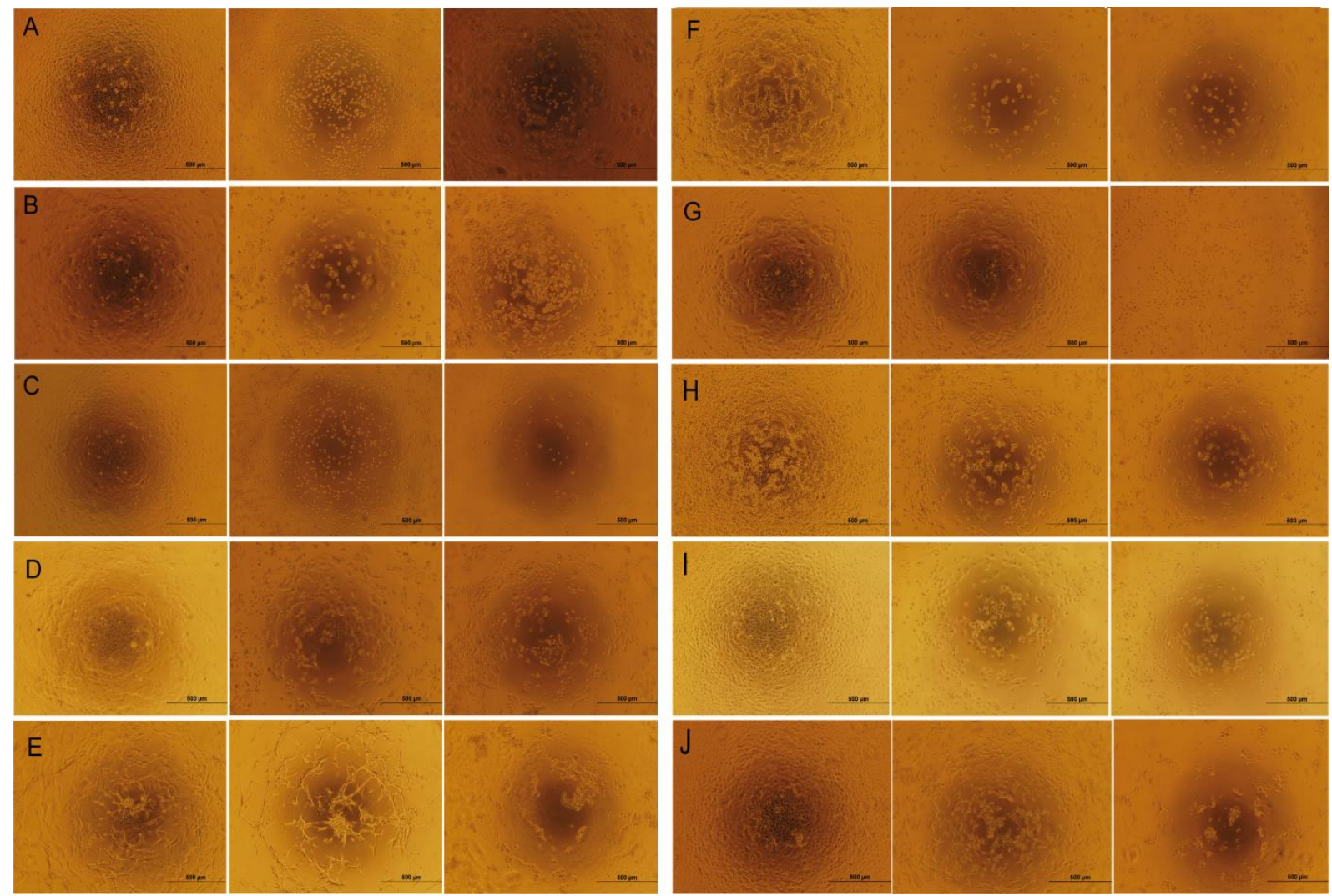

Figure S8. Microscopic examination of cancerous and non-cancerous (HEK293) cells compared to the control group $48 \mathrm{~h}$ after treatment with test compounds. Each panel shows non treated cells (left) compared to cells treated with xanthomonic acid $(20 \mu \mathrm{g} / \mathrm{mL})$ (middle) and the sesquiterpene lactone parthenolide $(12.5 \mu \mathrm{g} / \mathrm{mL})$, as positive control (right). The cell lines are: A. HeLa (Cervix) B. Caco-2 (Colorectum) C. MDA-MB-231 (Breast, estrogenindependent) D. MCF7 (Breast, estrogen-dependent) E. U87MG (Brain) F. HEK293 (Embryonic Kidney) G. A549 (Lung) H. mPanc-96 (Pancreas) I. PC3 (Prostate) J. 253J-BV (Bladder). 